\title{
Mapping Issues of Textile Industry of Pakistan with Trade Policy Framework
}

\author{
Abdul sattar Shah \\ Assistant Professor-IBA-University of Sindh-Jamshoro \\ Mushtaque Ali Jariko \\ PhD student-Department of Learning and Philosophy \\ Aalborg Universitet København / Aalborg University Copenhagen \\ AC Meyers Vænge 15,3.sal \\ 2450 København SV \\ Mr. Sarmad Rahat \\ Lecturer, Department of Economics \\ Shah Abdul Latif University-Khairpur-Mirs \\ Faiz Muhammad Shaikh \\ Assistant Professor-SZABAC-Dokri
}

\begin{abstract}
The current research investigates Mapping Issues of Textile Industry of Pakistan with Trade Policy Framework. Data were collected from Primary as well as secondary sources it is a statistical research technique in decision making that is used for the selection of a limited number of tasks that produce significant overall effect. It separates the few major problems from the many possible problems. It is named after Vilfredo Pareto, a 19th-century Italian economist. It can summarize all types of data. It can be applied to almost anything. It was revealed that four issues may be solved by the Government through trade policy of Pakistan as shown in figure 7-12 below. First and issue that in the international Markets Preferential Treatment is provided to the competitors and the second issue about Imposition of Anti-dumping duties on Pakistan's exports may be solved by Rationalizing Tariff Protection Policy (TPP) High tariff protection maintained over a period of time tends to erode competitiveness and affects consumer welfare. Therefore to protect Industry from High Tariffs, Ministry of Commerce will adopt some guiding principles to create a competitive environment that caters for dual aspects of providing level playing field for Pakistani firms in international markets; By Signing Favorable international agreements, Promote competitive markets in Pakistan, Ensure conformity to international agreements and practices, Promote domestic and foreign investment, Create level playing field for Pakistani firms in international as well as domestic markets, Due consideration to consumer welfare, Cater to the changing needs of Pakistan's economy and create an enabling environment to pursue the legitimate goal of Industrialization in Pakistan. Due to the prompt implementation of the above policy measure by Government on $12^{\text {th }}$ December 2013 European Union granted GSP-Plus status to Pakistan, It gives exporters duty-free access to 27 European countries. GSP (Generalized system of Preference) is exemption of WTO member countries from tariffs by considering as a least developed nation and granted till 2017. It is a chance to export more than US\$1 billion worth of products and earn profits of more than Rs1 trillion per year.
\end{abstract}

Key Words: Mapping, Textile, Industry, Pakistan.

\section{Council for Innovative Research}

Peer Review Research Publishing System

Journal: International Journal Of Management \& Information Technology

Vol . 10, No 6

editorsijmit@gmail.com

www.ijmit.com 


\section{Introduction}

To solve the problems of industry country's Government plays an important role. In case of industrial problems associated with trade Government solves the issues through trade policy. Therefore, it was decided to compare the issues of textile industry of Pakistan with the trade policy of Pakistan to find how much Government has done to solve the issues of textile industry in the era of trade liberalization.

To address the concerns of business community instead of annual trade policies in 2009Government launched the first three yearstrategic trade policy framework that was from 2009-12. In 2013Government launched the second 3 yearstrategic trade policy framework that was from 2012-15. This initiative has served the purpose of giving a medium term outlook to our policy regime.

Therefore, the second three yearstrategic trade policy framework from 2012-15 was taken into account for mapping the issues of textile industry of Pakistan and find the issues that may be solved by Government through trade policy measures. Furthermore, the reduced issues selected after Pareto analysis are undertaken for mapping with trade policy framework.

\subsubsection{Major Elements of the Trade Policy Framework 2012-15}

The major elements of the Trade Policy Framework 2012-15 are as follows:

- Focus on regional trade

- Strengthening of the institutional framework for promotion of exports

- Creation of regulatory efficiencies

- $\quad$ Export development initiatives

- Increase exports from less developed regions of Pakistan

- Promotion of domestic commerce

- Strengthen the monitoring and evaluation mechanism

\subsubsection{Major Trade Policy Decisions Related to Textile Industry}

The details of some major trade policy decisions related to textile industry are highlighted below:

- Establishment of Pakistan Land and Port Authority(PLAP) to strengthen regional trade

- $\quad$ Setting up of Exim (Export/Import) Bank

- Creating Regulatory Efficiencies

- Strengthening of Training and Product Development Institutes

- Revamping Export Promotion Agencies \& Trade Monitoring Committee

- Up gradation of Agriculture Sector

- Export promotion campaigns for agro-processed products

- Encouraging the opening of Retail Outlets

- Strengthening Women Chamber of Commerce

- Regulatory amendments in Trade Regulations

\subsection{INTERNAL ISSUES}

The same sequence of first selecting internal issues then National and finally global has been followed.

\subsubsection{Internal Issues of Spinning}

The reduced issues of spinning sector after Pareto analysis are presented below:

- Contaminated cotton is used in spinning

- Low quality of yarn

- $\quad$ Lower returns from selling yarn in International Markets

- Improper handling methods of cotton

\subsection{1-1 Mapping Internal Issuesof Spinning Sector}

The internal issues of spinning sector are mapped with the major elements of trade policy framework 2012-15 to highlight the issues that may be solved by Government through trade policy of Pakistan as shown in figure 7-1 below. 


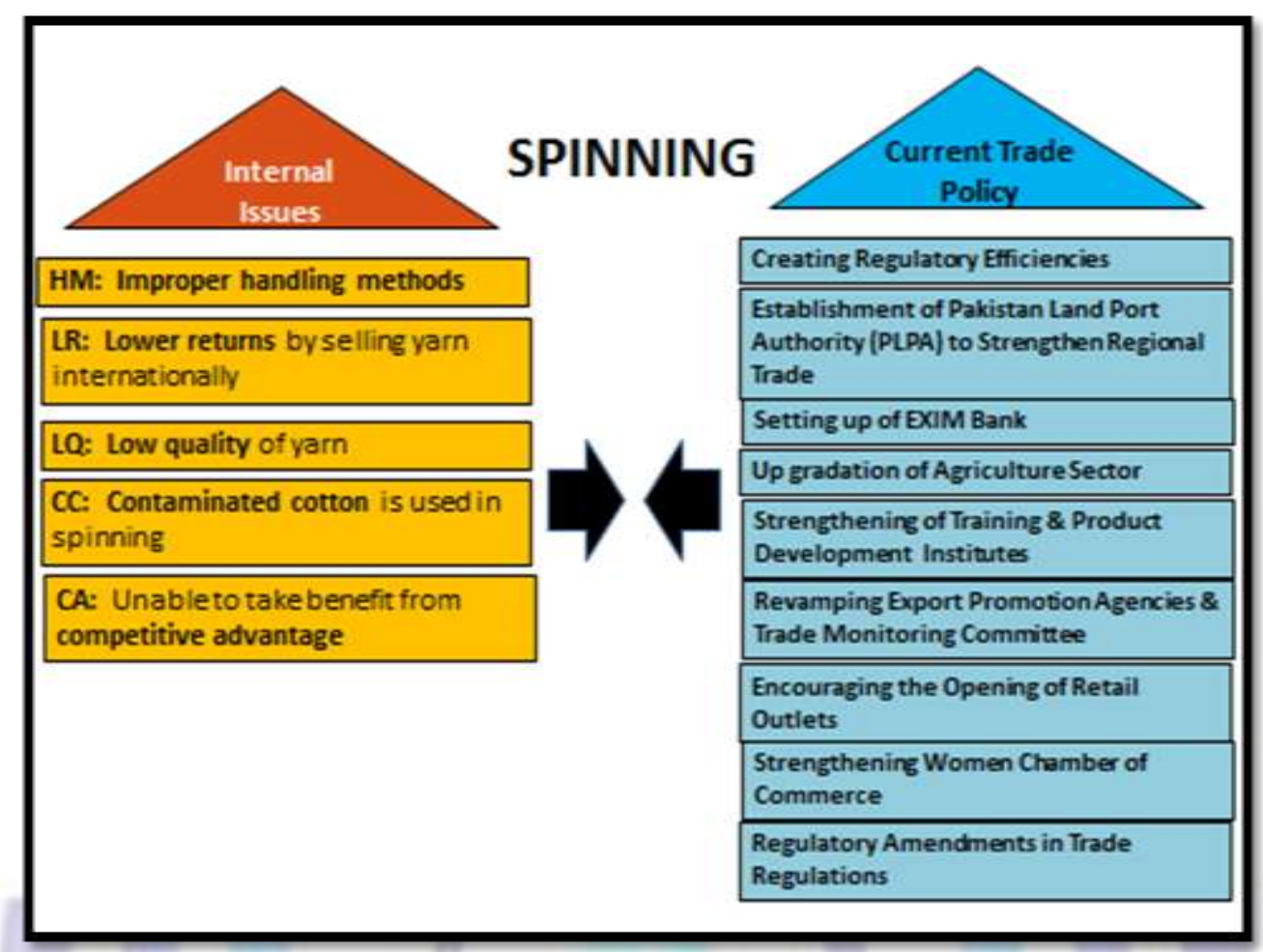

Figure: 7-1 Internal Issues of spinning \& Major Elements of Trade Policy

After mapping the internal issues of spinning sector with the major elements of trade policy framework 2012-15 it has been found that one issue may be solved by the Government through trade policy of Pakistan. It is the issue of contamination content in cotton that is used in spinning that may be solved by Up Gradation of Agriculture sector as shown in figure 7-2 below. Furthermore, it has been found that Government has started up grading the agriculture sector by opening Farmer Field Schools that is a Season Long Training for Farmers, Established under Provincial Community Integrated Pest Management Project and Seminars on "Grow more 2013", held on 30 ${ }^{\text {th }}$ Nov. 2013 At hotel Indus by Agriculture Department for educating the agriculturists as well as the farmers. In order to help our farmers align themselves better with the international market, it has been decided to launch export promotion campaigns with the help of graduates of agriculture universities of Pakistan. Selected students will be trained to reach out to the farmer community and train them in best agricultural practices needed to bring their produce in conformity with the international standards.

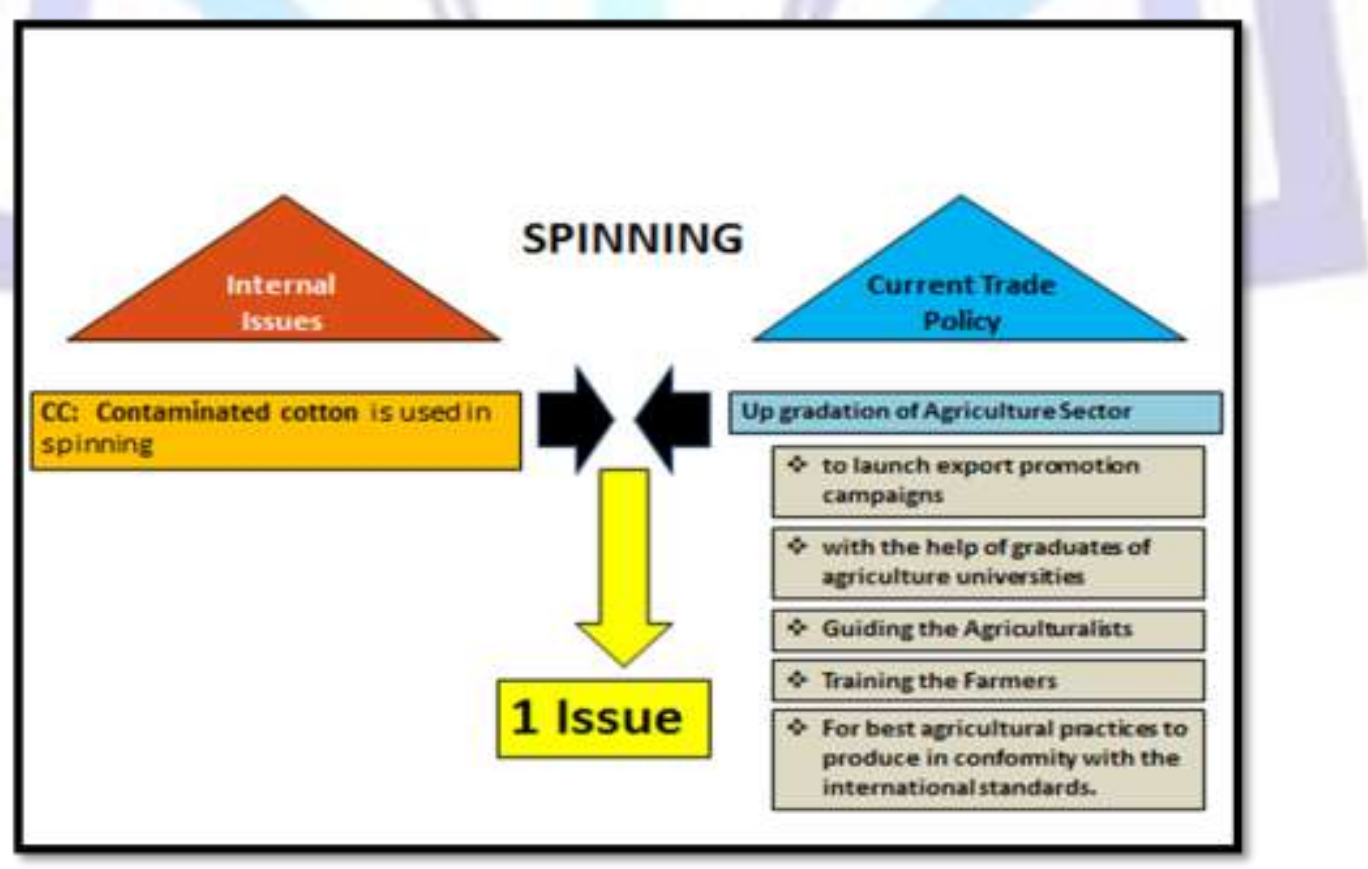

Figure: 7-2 Mapping Internal Issues of spinning with Major Elements of Trade Policy 


\subsubsection{Internal Issues of Weaving}

The reduced issues of weaving sector after Pareto analysis are presented below:

- Non availability of Testing Laboratories

- Lack of Value Addition

- Weaving is mostly based on Wide Width

- Outdated Machinery

\subsection{2-1 Mapping Internal Issuesof Weaving}

The internal issues of weaving sector are mapped with the major elements of trade policy framework 2012-15 to highlight the issues that may be solved by Government through trade policy of Pakistan as shown in figure 7-3 below.

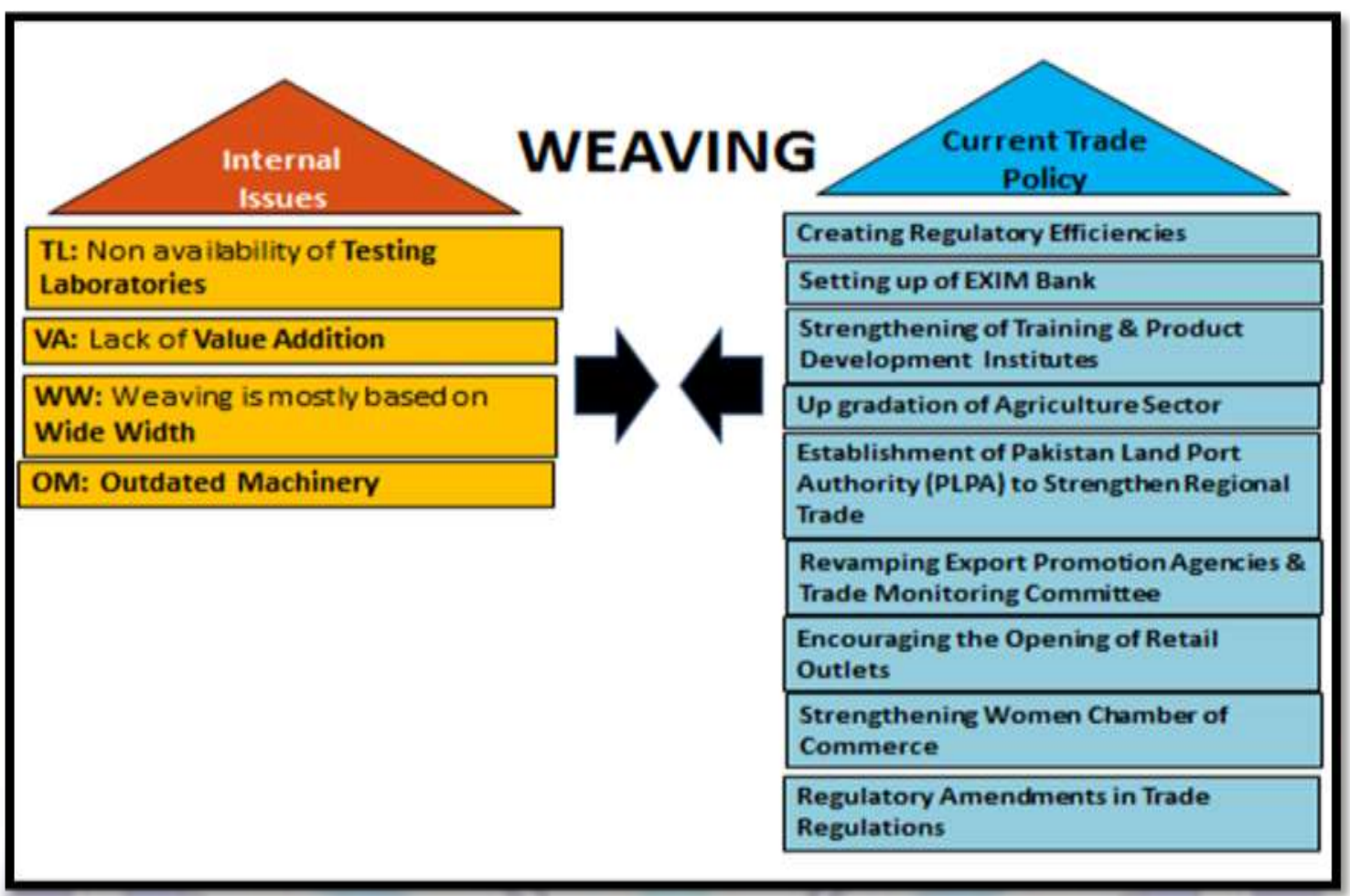

Figure: 7-3 Mapping Internal Issues of Weaving with Major Elements of Trade Policy

\subsection{2-2 Results ofMapping Internal Issuesof Weaving}

After mapping the internal issues of weaving sector with the major elements of trade policy framework 2012-15 it has been found that two issues may be solved by the Government through trade policy of Pakistan as shown in figure 7-4 below. First, the issue of outdated machinery used in weaving sector may be solved by Export Development Initiatives through which mark-up support of $2 \%$ for the purchase of latest machinery. Long Term Financing Facility (LTFF) of State Bank of Pakistan is aimed at providing relatively concessional financing to manufacturer cum exporters for the purchase of Latest Machinery.

Second, the issue of lack of value addition may be solved by Strengthening of Training \& Product Development Institutes, To carry out a detailed 'entity improvement diagnostic and audit for institutions to produce better quality human resource, So that a variety of value added products may be produced. 


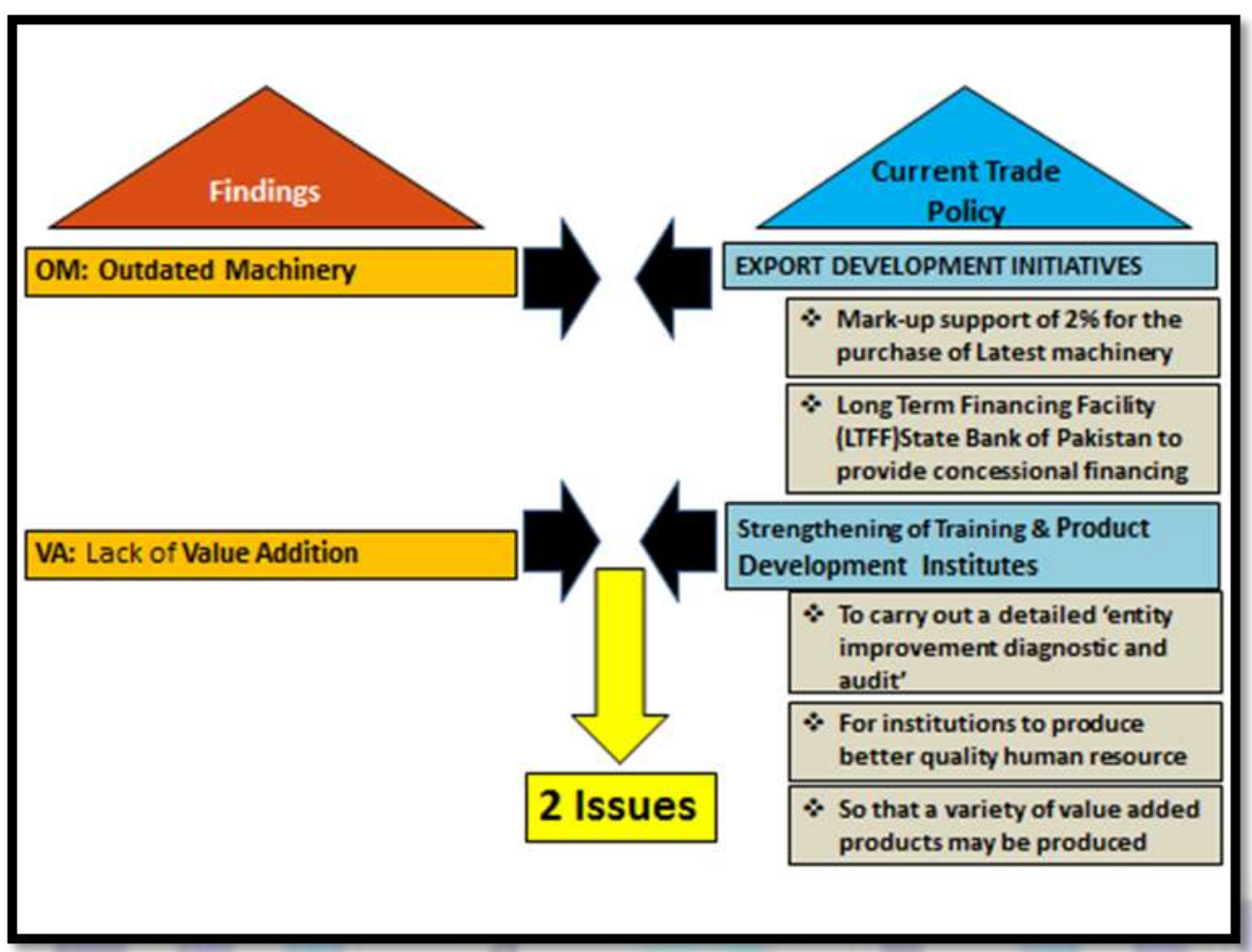

Figure: 7-4 Selected Issues of Weaving after mapping

\subsubsection{Internal Issues of Processing}

The reduced issues of processing sector after Pareto analysis are presented below:

- Desired shades are not possible with Poor Quality of Water

- Antique Methods of Dying and Printing

- Inconsistency in Color/Shades

- Foreign Buyers have become more conscious

\subsection{3-1 Mapping Internal Issuesof Processing}

The internal issues of processing sector are mapped with the major elements of trade policy framework 2012-15 to highlight the issues that may be solved by Government through trade policy of Pakistan as shown in figure 7-5 below.

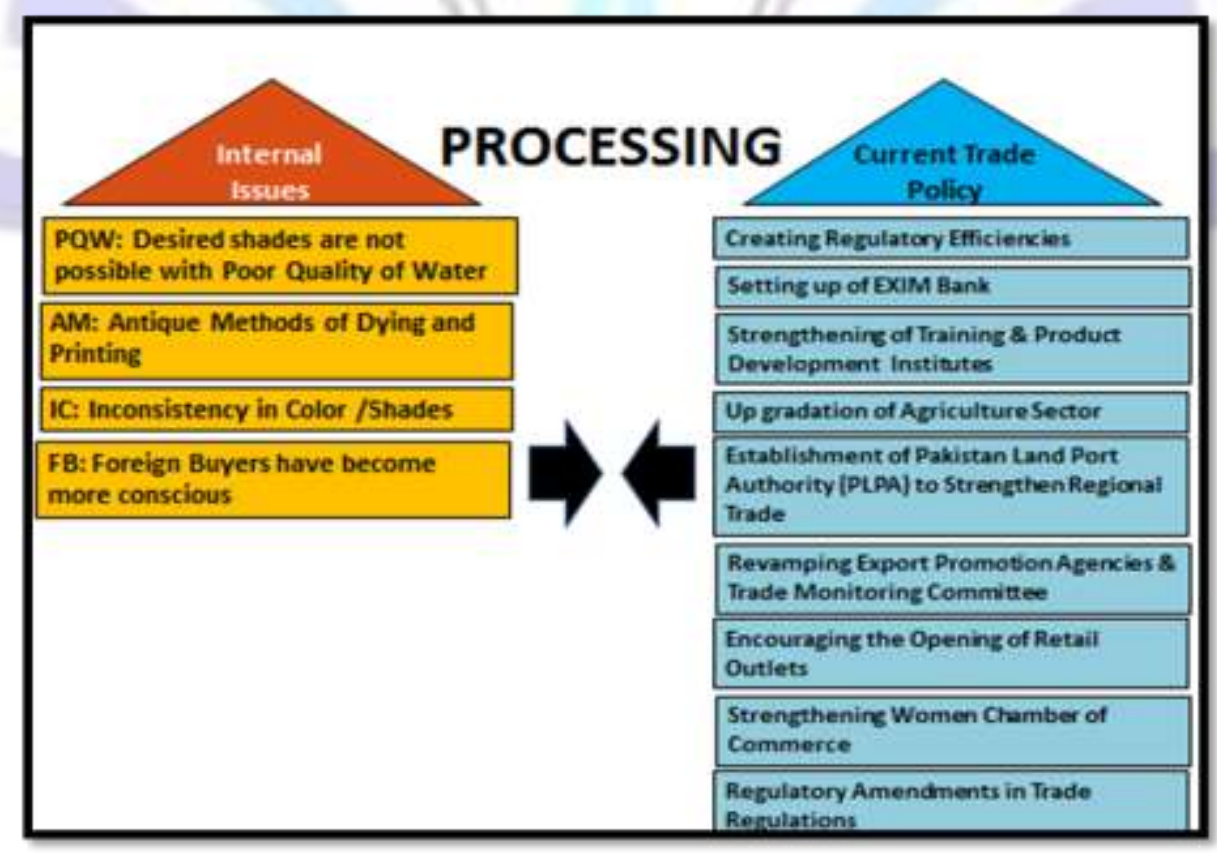

Figure: 7-5 Mapping Internal Issues of Processing with Major Elements of Trade Policy 


\subsection{3-1 Results of Mapping Internal Issuesof Processing}

After mapping the internal issues of processing sector with the major elements of trade policy framework 2012-15 it has been found that two issues may be solved by the Government through trade policy of Pakistan as shown in figure 7-6 below. It is the issue of Antique Methods of Dying and Printing that may be solved by Strengthening of Training \& Product Development Institutes, to carry out a detailed 'entity improvement diagnostic and audit for institutions to produce better quality human resource, So that to produce latest designs by using latest techniques of dying \& Printing.

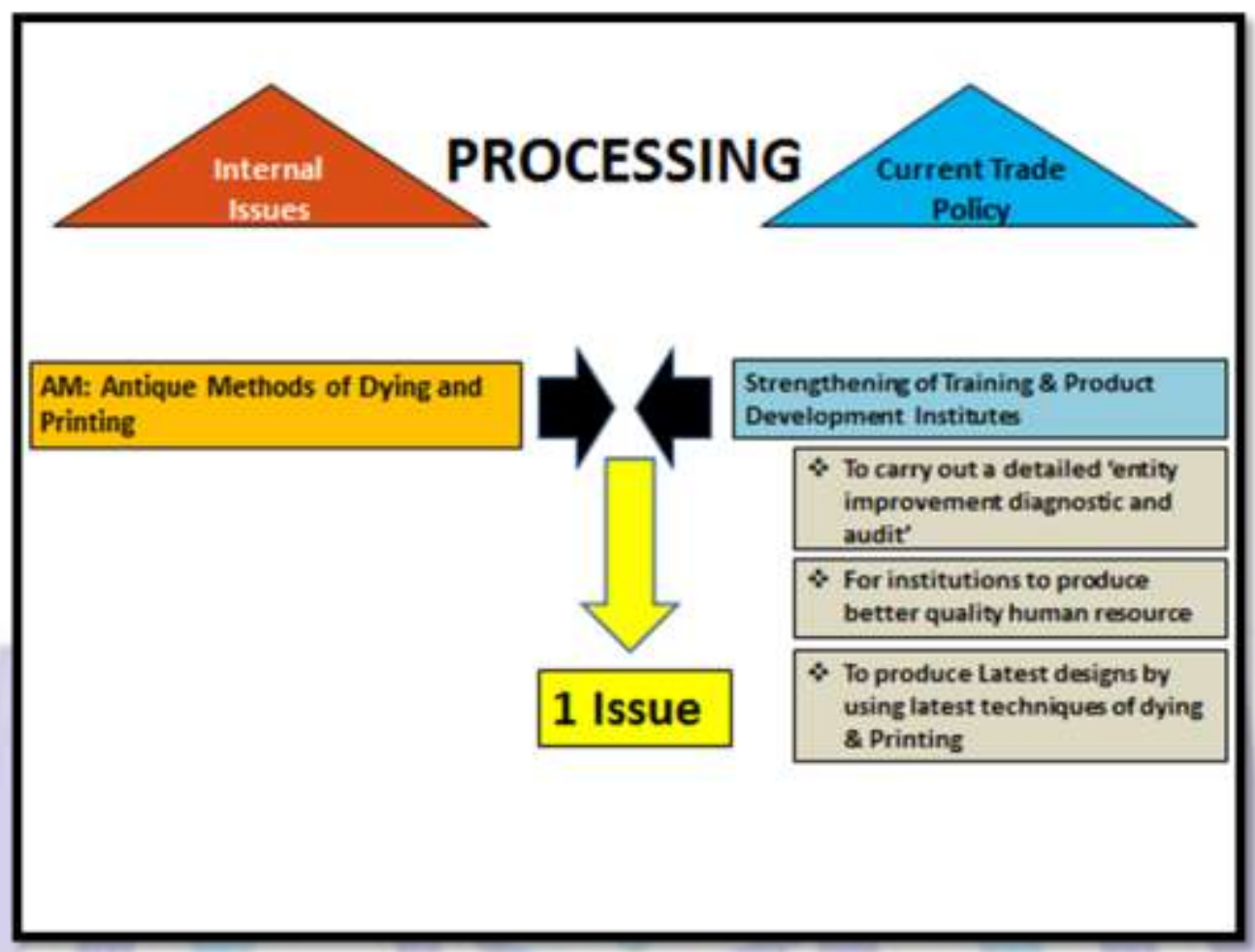

Figure: 7-6 Selected Issues of Processing after Mapping with Trade Policy

\subsubsection{Internal Issues of Garments}

The reduced issues of processing sector after Pareto analysis are presented below:

- $\quad$ Competing countries taking benefit by Labeling the Made-Ups produced from Pakistan

- Higher chance of Defected Production

- $\quad$ Lack of International Market Research for wakefulness about the global brands

- Lack of Computer Added Design

- Always searched for the demand of Cheaper Garments

- Most of the business is established in Small Shops, Flats and houses

- Huge Investment is made in Spinning \& Weaving

\subsection{4-1 Mapping Internal Issuesof Garments}

The internal issues of Garments sector are mapped with the major elements of trade policy framework 2012-15 to highlight the issues that may be solved by Government through trade policy of Pakistan as shown in figure 7-7 below. 


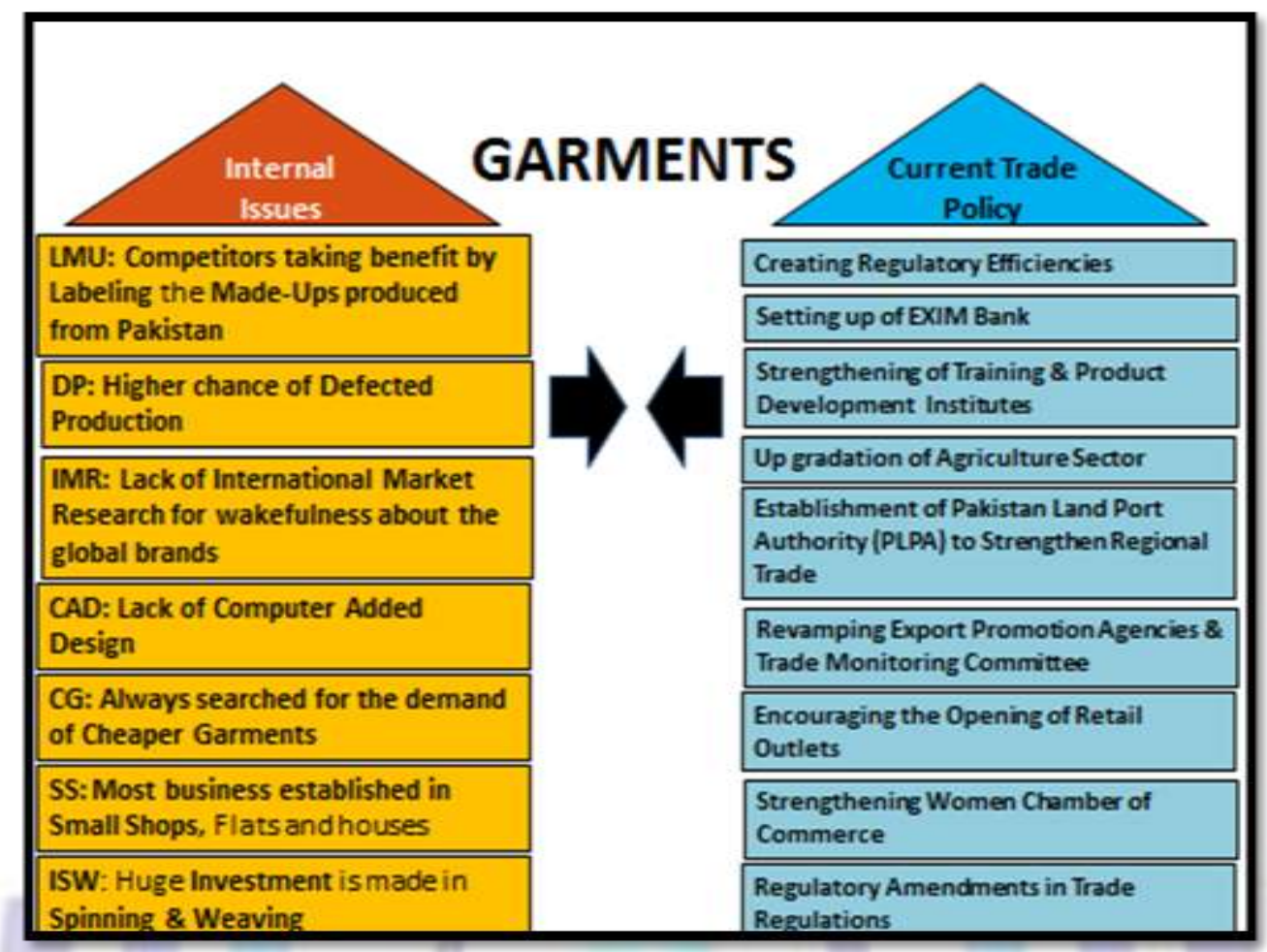

\section{Mapping Internal Issues of Garments with Major Elements of Trade Policy}

\section{Results ofMapping Internal Issuesof Garments Sector}

After mapping the internal issues of garments sector with the major elements of trade policy framework 2012-15 it has been found that two issues may be solved by the Government through trade policy of Pakistan as shown in figure 7-8 below. First, the issue of Huge Investment is made in Spinning \& Weaving sector only may be solved by Setting up of EXIM (Export Import) Bank; to provide financing, to provide export credit guarantees and to ensure that adequate, cheap and timely trade financing is made available for all sectors.Pakistan's exporters also need legitimate trade financing support in the wake of challenges of high interest rates and limited availability of financing for export or investment in export oriented manufacturing as well inadequate incentives to import from Pakistan as compared to our competitors. A committee has been constituted under the chairmanship of Governor State Bank to work out detailed modalities for establishing the EXIM Bank.

Second issue about the lack of International Market Research for wakefulness of the global brands may be solved by Marketing Development Assistance; to up-scale market development activities in Regional Markets different promotional initiatives are undertaken that include International Market Research for Global Brands.

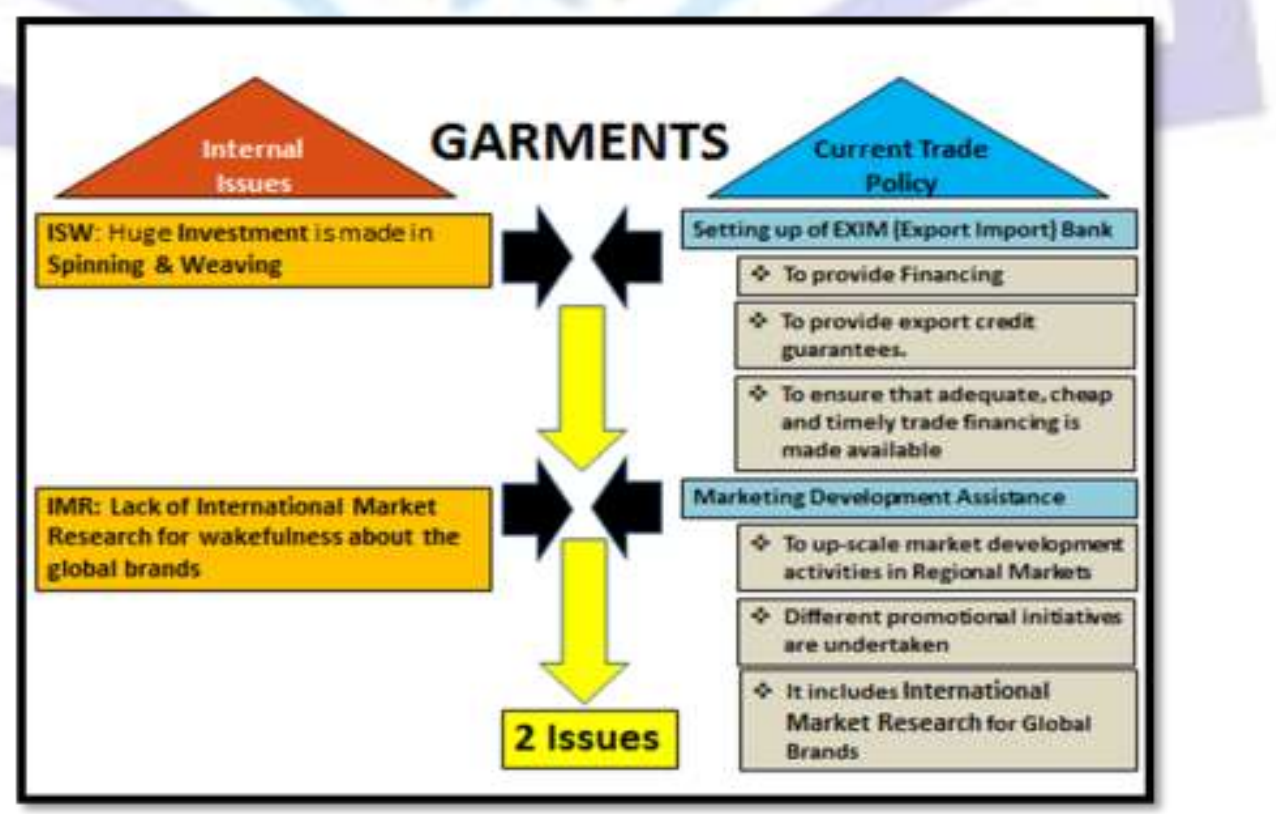




\section{Figure: 7-8 Selected Issues of Garments Sector after Mapping with Trade Policy}

\subsection{NATIONAL ISSUES}

The reduced National issues after Pareto analysis are presented below:

- High Cost of production

- Government Departments are thought to be Constraints

- There is no any Collective Method for solving industrial problems

- $\quad$ Lack of Interaction between Industry and Academia

- Decline in exports is due to the Shifting of Textile Business to other countries

- Lack of Funds to promote textile business

- Industrialists are Highly Risk-Averse

- $\quad$ Experienced Labors are Shifting to other countries

- Lack of Research\&Development

\section{Mapping National Issues}

The National issues are mapped with the major elements of trade policy framework 2012-15 to highlight the issues that may be solved by Government through trade policy of Pakistan as shown in figure 7-9 below.

\begin{tabular}{|c|c|}
\hline HCP: High Cost of production & Creating Regulatory Efficiencies \\
\hline \multirow{2}{*}{$\begin{array}{l}\text { GDC: Government Departments are } \\
\text { bel ieved to be Constraints in the } \\
\text { development of textile industry }\end{array}$} & Setting up of EXIM Bank \\
\hline & $\begin{array}{l}\text { Strengthening of Training \& Product } \\
\text { Development Institutes }\end{array}$ \\
\hline \multirow{2}{*}{$\begin{array}{l}\text { CM: There is no any Collective } \\
\text { Method of solving industrial } \\
\text { problems }\end{array}$} & Up gradation of Agriculture Sector \\
\hline & Establishment of Pakistan Land Port \\
\hline $\begin{array}{l}\text { IIA: Lack of Interaction between } \\
\text { Industry and Academia }\end{array}$ & $\begin{array}{l}\text { Authority (PLPA) to Strengthen Regional } \\
\text { Trade }\end{array}$ \\
\hline \multirow{2}{*}{$\begin{array}{l}\text { STB: Decline in exports is due to the } \\
\text { Shifting of Textile Business to other } \\
\text { countries }\end{array}$} & $\begin{array}{l}\text { Revamping Export Promotion Agencies \& } \\
\text { Trade Monitoring Committee }\end{array}$ \\
\hline & \multirow{2}{*}{$\begin{array}{l}\text { Encouraging the Opening of Retail } \\
\text { Outlets }\end{array}$} \\
\hline $\begin{array}{l}\text { LF: Lack of Funds to promote textile } \\
\text { business }\end{array}$ & \\
\hline HRA: Highly Risk-Averse Industrialists & $\begin{array}{l}\text { Strengthening Women Chamber of } \\
\text { Commerce }\end{array}$ \\
\hline $\begin{array}{l}\text { LS: Experienced Labors are Shifting to } \\
\text { other countries }\end{array}$ & $\begin{array}{l}\text { Regulatory Amendments in Trade } \\
\text { Regulations }\end{array}$ \\
\hline RD: Lack of Research \& Development & \\
\hline
\end{tabular}

\section{FMapping National Issues with Major Elements of Trade Policy}

\section{Results ofMapping National Issues with Trade Policy}

After mapping the National issues with the major elements of trade policy framework 2012-15 it has been found that four issues may be solved by the Government through trade policy of Pakistan as shown in figure 7-10 below. First, the issue of There is no any Collective Method of solving industrial problems may be solved by Creating Regulatory Efficiencies. Second, the issue of Lack of Funds to promote textile business may be solved by Setting up of EXIM (Export Import) Bank. Third issue that some Government departments are believed to be Constraints in the development of textile industry \& fourth issue of Lack of Interaction between Industry and Academia both may be solved by Revamping Export Promotion Agencies \& Trade Monitoring Committee.

It has been decided to constitute a high level 'Trade Committee under the chairmanship of Commerce Minister, with membership from relevant government Ministries/departments, provincial governments, business and academia. In this way a linkage would be developed between government, business and academia to solve the problems Pakistan's foreign trade. The committee would be mandated to evaluate our trade performance at least on a quarterly basis and address specific issues hampering Pakistan's foreign trade and competitiveness. Furthermore, trade Committee has decided to develop a linkage between the government, business and academia to solve trade problems. 


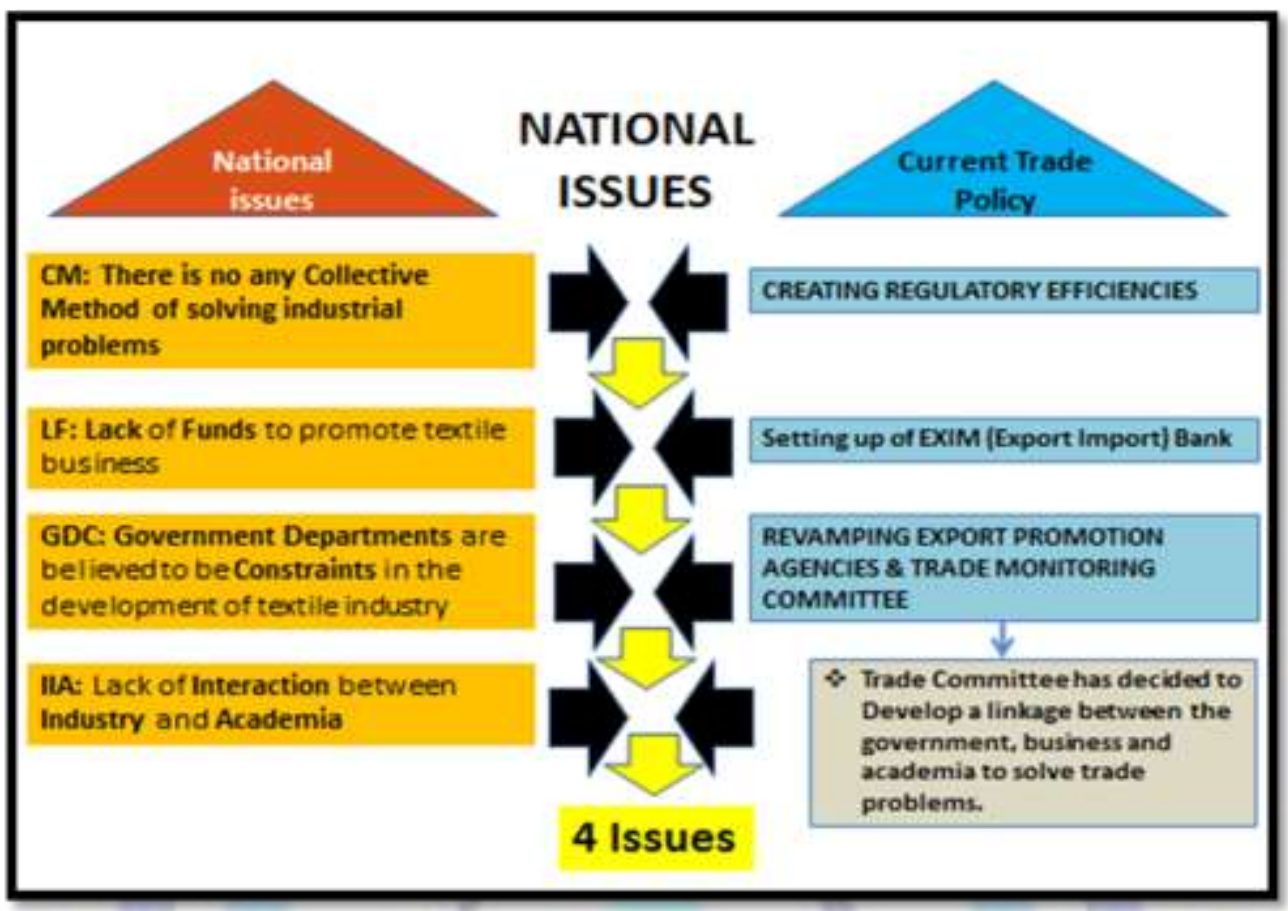

Figure: 7-10 Selected National Issues after Mapping with Trade Policy

\section{GLOBAL ISSUES}

The reduced Global issues after Pareto analysis are presented below:

- $\quad$ Lack of Effluent Treatment Plant (ETP)

- WTO is believed to be a Threat to our EconomicStanding

- Evaluationof the factory by the international buyers

- Highly Labor-Intensive Production

- Worse Image of Pakistan internationally

- In the international Markets Preferential Treatment is provided to the competitors

- Millions of dollars spent to DestroyPakistan's Image internationally

- Quality issues

- Lack of awareness about trade liberalization

- Not in a Position to Protect Our Interest \& get relief from competent courts of law

- Increase in ForeignBuyer Check

- Imposition of Anti-Dumping Duties on textile exports

- $\quad$ Lack of Diversification in the direction

- Not understood what Globalization \& WTO are

- Restrictions of EU to buy the raw material from them

- WTO has affected Trade \& Industry Negatively

\section{Mapping Global Issues}

The Global issues are mapped with the major elements of trade policy framework 2012-15 to highlight the issues that may be solved by Government through trade policy of Pakistan as shown in figure 7-11 below. 


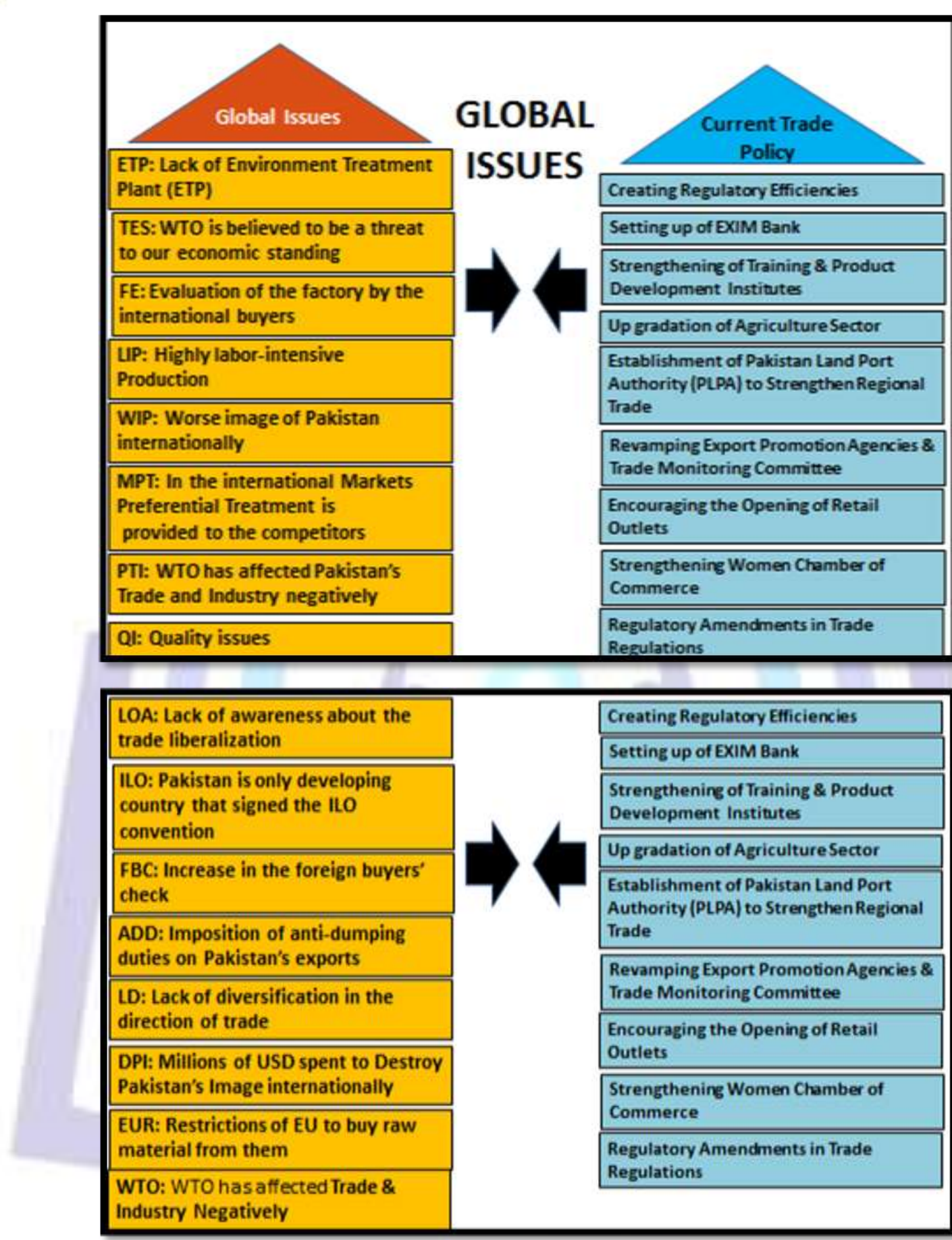

\section{Mapping National Issues with Major Elements of Trade Policy \\ Results of Mapping Global Issueswith Trade Policy}

After mapping the Global issues with major elements of trade policy framework 2012-15 it is found that four issues may be solved by the Government through trade policy of Pakistan as shown in figure 7-12 below. First and issue that in the international Markets Preferential Treatment is provided to the competitors and the second issue about Imposition of Antidumping duties on Pakistan's exportsmay be solved by Rationalizing Tariff Protection Policy (TPP) High tariff protection maintained over a period of time tends to erode competitiveness and affects consumer welfare. Therefore to protect Industry from High Tariffs, Ministry of Commerce will adopt some guiding principles to create a competitive environment that caters for dual aspects of providing level playing field for Pakistani firms in international markets; By Signing Favorable international agreements, Promote competitive markets in Pakistan, Ensure conformity to international agreements and practices, Promote domestic and foreign investment, Create level playing field for Pakistani firms in international as well as domestic markets, Due consideration to consumer welfare, Cater to the changing needs of Pakistan's economy and create an enabling environment to pursue the legitimate goal of Industrialization in Pakistan. Due to the prompt implementation of the above policy measure by Government on $12^{\text {th }}$ December 2013 European Union 
granted GSP-Plus status to Pakistan, It gives exporters duty-free access to 27 European countries. GSP (Generalized system of Preference) is exemption of WTO member countries from tariffs by considering as a least developed nation and granted till 2017. It is a chance to export more than US\$1 billion worth of products and earn profits of more than Rs 1 trillion per year.

Third the Quality issues may be solved by Strengthening of Training \& Product Development Institutes. The training and product development institutes running under Ministry of Commerce and TDAP will be strengthened after carrying out a detailed 'entity improvement diagnostic and audit'. This would help these institutions to produce better quality human resource and produce latest designs for textile industry of Pakistan.

Fourth issue about Lack of diversification in the direction of trade may be solved through Encouraging Opening of Retail Outlets. Opening retail sale outlets in major importing countries is the best tool for introducing and exporting exports of Pakistan in different countries. International presence of Pakistani firms at present is very low as compared to our competitors. To diversify the direction of trade in different countries, it has been decided to provide subsidy on opening the outlets of up to 75 percent, 50 percent, 25 percent per annum of the rental cost of retail outlets or ware houses in the first, second and third year respectively in the export markets in Asia, Africa and Australia.

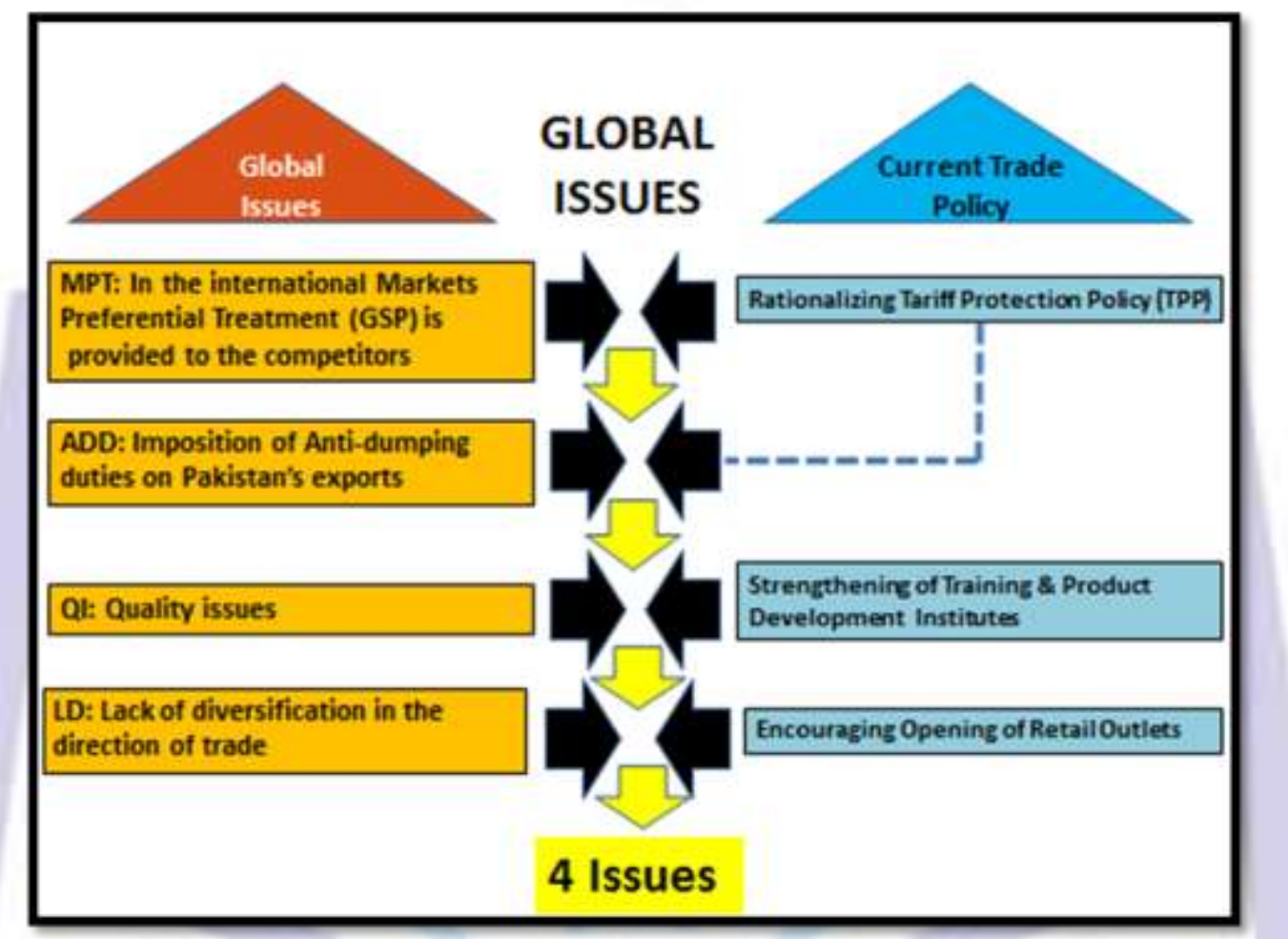

Figure: 7-12 Selected Global Issues after Mapping with Trade Policy

\section{CONCLUSIONS}

For resolving the issues of textile industry of Pakistan an attempt was made to assess what role Government of Pakistan has played so far to solve the issues related to the success of textile industry in the era of trade liberalization. Therefore, it was decided to map the prioritized issues reduced through Pareto analysis with the trade policy framework 2012-2015. After mapping the Internal, National and Global issues separately it is found that out of selected 45 issues about 14 issues may be solved by the Government as presented in Figure 7-13 and 7-14 below. The result of mapping may also be seen in the table 7-1 presented below.

1. Calle, Alejandra M., 2012, "Environmental Concerns and Trade Disputes: An Overview from the GATT and the WTO Dispute Settlement System". Cork Online Law Review. [2012] COLR 48. p.48-64. Eleventh Edition. Available online

2. Lindeque J. and McGuire S., 2010 'Building Non-Market Capabilities: A Resource-based View of Prosecuting a Trade Remedy Case', Journal of World Trade, 44(4): 303-343.

3. Mirza S. B, 2009, "Textile Industry", Economic Pakistan, online available, http://economicpakistan.wordpress.com/2009/02/01/textile-industry 
4. Haider M. Z, 2007, "Competitiveness of the Bangladesh Ready-made Garment Industry in Major International Markets", Asia-Pacific Trade and Investment Review Vol. 3, No. 1, June 2007

5. Kaibin Z., Mehta M., Sinha A. \&Inngi B. L. 2007, "Shaping up for the race", Staff Reporters, ATA, Journal of Asian Textile \& Apparel, Feb. 2007, Kabin Z. is Vice Director of the Hubei Provincial Textile Industrial Investment Acceleration Center.

6. Nair D. K, 2007, "Post quota scene in T \& C industry", Focus WTO a news \& views magazine Vol. 8 no. 5 Textile \& Clothing, Jan.-Feb.2007, D.K.Nair is a Secretary General, Confederation of Indian textile industry (Citi.), new Delhi.

7. Burki S. J, 2006, "WTO and Pakistan: Multilateral Trading System", South Asian Journal, Issue -12.

8. Liaquat F, Hassan M, 2005, "Biological Treatment of Textile mill waste water in presence of activated carbon", Environmentally Sustainable Development, Volume II, Department of Environmental Sciences, Comsats, Institute of Information Technology.

9. Kelegama S., 2005, "Ready-Made Garment Industry in Sri Lanka: Preparing to Face the Global Challenges" Asia-Pacific Trade and Investment Review Vol. 1, No. 1, April 2005

10. Rafi K. S., 2005, " Impact of WTO on the Patterns of Trade in Textile \& Clothing”, Journal of Management and Social Sciences, Vol. 1, No. 2, (Autumn 2005) 204-226

11. Sasi A, 2005, "Asian Textile Nations to Join Hands to Rule Global Markets", Business Line, International Edition, Financial Daily from the Hindu Group of Publications Sunday, Sep. 4, 2005.

12. Sheikh H, 2005, "Pakistan bed linen exports: Problems \& Prospects ", Pakistan Textile Journal

13. Viqar S, 2005, "Brand Development and the Role of Designers in WTO ", Pakistan Textile Journal

14. Weeraratne B, 2005,"Labour Standards and International Trade : The Case of EU GSP Concessions to Srilanka", Working Paper Series No: 8.

15. Kashif R. S, 2005, "Impact of WTO on the Patterns of Trade in Textile \& Clothing", Journal of Management and Social Sciences, Vol. 1, No. 2, (Autumn 2005) 204-226

16. Baig M, 2004, "Global scenario of textiles and position of Pakistan ", Pakistan Textile Journal.

17. Haverson K, 2004, "China's WTO accession: Economic, Legal and Political Implications", Journal Contents, (Publication Students Homepage).

18. Kelegama, S., 2004, "Ready-Made Garment Industry in Sri Lanka: Facing the Global Challenge", Institute of Policy Studies, Colombo.

19. Council Regulation (EC) No 980/2005 of 27 June 2005, "Applying a scheme of generalised tariff preferences", Official Journal L 169, 30/06/2005 P. 0001 - 0043.

20. MTDF (Medium term development Framework 2005 - 10) Planning Commission Government of Pakistan, May 2005.

21. United States International Trade Commission (USITC) 2004, Textile and Apparel: Assessment of the Competitiveness of Certain Foreign Suppliers to the U.S. Market, Vol. 1, USITC, Washington, D.C.

22. RIS (2004). South Asia Development and Cooperation Report 2004, Research and Information System for NonAligned and Other Developing Countries, New Delhi.

23. UNCTAD (2003), "The African Growth and Opportunities Act: A Preliminary assessment", (UNCTAD/ITCD/TSB/2003/1).

24. IPS (2003), Sri Lanka: State of the Economy - 2003, Institute of Policy Studies, Colombo, Sri Lanka.

25. ILO (2002), "Garment Industry in South Asia: Rags or Riches? Competitiveness, Productivity, and Job Quality in the Post-MFA Environment", ILO, New Delhi.

26. JAAF (2002), "5 Year Strategy for the Sri Lankan Apparel Industry”, Joint Apparel Association Forum, Colombo. 